\title{
Genetically modified crops in Switzerland: implications for agrosystem sustainability evidenced by multi-criteria model
}

\author{
Doris Wohlfender-Bühler ${ }^{1} \cdot$ Elisabeth Feusthuber ${ }^{2} \cdot$ Robert Wäger $^{1}$ • \\ Stefan Mann ${ }^{2} \cdot$ Sylvain J. Aubry ${ }^{1}$
}

Accepted: 29 March 2016/Published online: 2 May 2016

(C) The Author(s) 2016. This article is published with open access at Springerlink.com

\begin{abstract}
In Switzerland, genetically modified (GM) crops have been banned in 2005 and have never been used in agriculture. The relevance and sustainability of genetically modified crops for agrosystems have been assessed following a mandate from the Swiss Parliament defined by the Federal Act on Agriculture (187d al.1). For that, an ex ante study based on a multi-criteria decision analysis model that summarises literature and the opinion of experts has been done.

The impacts of genetically modified crops on both environmental and socio-economical sustainability in Switzerland have been assessed. Here, we review four model crops for Swiss agriculture: maize, sugar beet, potato and apple. Each crop was compared for both conventional and genetically modified farming systems that contain a specific trait, namely insecticide production (Bacillus thuringiensis (Bt)), herbicide tolerance (HT), fungal resistance (FR), or bacterial resistance (BR). Results show that six out of seven scenarios showed a lower socio-economical sustainability for genetically modified compared to the conventional systems, whereas a slight improvement in the environmental component, mostly resources use, was observed in all scenarios. In conclusion, our work indicates that only carefully tailored and designed genetically modified
\end{abstract}

Elisabeth Feusthuber and Robert Wäger contributed equally to this work.

Sylvain J. Aubry

sylvain.aubry@blw.admin.ch

1 Federal Office for Agriculture, Mattenhofstrasse 5, Bern 3003, Switzerland

2 Agroscope Tänikon, Tänikon 1, Ettenhausen 8356, Switzerland crops would meet the high standard of requirements of Swiss agrosystems. Our model has thus allowed a quick diagnostic on the impact of genetically modified cultivation on sustainability.

Keywords Sustainability · GM crops ·

Multi-criteria decision analysis · Switzerland $\cdot$ Ex ante $\cdot$ DEXi

\section{Contents}

1. Introduction

2. Methodology used for assessing sustainability of Swiss agrosystems

2.1 Qualitative multi-criteria decision analysis using MCDA

2.2 Definition of the model components

2.3 System boundaries

2.4 Comparison of seven cropping systems containing GMO or not

3. Effect of GM crops on sustainability of agrosystems

3.1 GM crops led to an overall lower socio-economic sustainability

3.2 Sensitivity analysis postulating high GM acceptance shows variations in sustainability

3.3 GM crops marginally improve environmental sustainability

4. Discussion

4.1 Distinction between short- and long-term sustainability is critical

4.2 Sustainability is impacted by coexistence measures

5. Conclusion

Acknowledgements

References 


\section{Introduction}

Almost 20 years after their introduction, genetically modified (GM) crops and their associated policies are still matter of strong controversies. As a non-European Union (EU) member state, Switzerland evolved its own regulatory processes. Both Swiss citizens and farmers expressed strong negative views in many national surveys with about $65 \%$ of the people opposed to GM plants in the last polls (Aerni et al. 2011; FAO 2015). This led the Parliament to pass a law on genetic technology in non-human organisms in 2004 (GTA, 814.91), followed by a referendum to ban GM crops (Wolf and Albisser Vögeli 2009). One of the aims of this law is to guarantee that genetic engineering "serves the welfare of human beings, animals and environment" (Gene Technology Act, 814.91, Art 1). This text, more generally, frames the regulation over green biotechnologies but also leaves room for their potential use to maintain or improve agricultural sustainability. The end of the ban on GM crops has been postponed three times by the Swiss Federal Council and Parliament to officially finish by the end of 2017. A large publically funded national research program (NRP59) consecutive of the referendum was launched to evaluate the costs and benefits of GM in the Swiss agricultural context. Both environmental and socio-economic studies were conducted in this program. The main conclusions were that GM crops commercially available at that time did not yield particular agronomical advantage to Swiss farmers and that global distaste of GM-containing food impaired chances to open a viable market for these crops (Speiser et al. 2013). Insecticide-producing (Bt toxin) and herbicide tolerance (HT) represent the vast majority of GM crops used worldwide (Benbrook 2012; Brookes and Barfoot 2013). Those GM crops have been proposed to improve global agricultural sustainability (Raymond Park et al. 2011) by claiming three main advantages: (1) increase in yield, (2) lowering pesticide use and (3) increase of farmer's income (Klümper and Qaim 2014). HT crops mostly present resistance to glyphosate or glufosinate so far. After more than 20year cultivation, some trends can be drawn on HT and Bt effects on pesticide use. On one hand, glyphosate use has massively increased in, e.g. cotton and soybean production systems (Jorge and Caswell 2006; Benbrook 2012; Klümper and Qaim 2014). Total pesticide use in the USA is stable over this period with around $2.4 \mathrm{t}$ of active ingredient used per 1000 ha (FAO 2015) showing that GM crop use did not globally prevent pesticide spraying (for detailed review, see Fernandez-Cornejo et al. 2014). On the other hand, Bt corn and cotton are estimated to save 56 million tons of insecticides in the USA on the same period of time (Benbrook 2012; Klümper and Qaim 2014) when the in planta-produced toxins and seed coating are not considered. Noteworthy, some additional advantages are associated to Bt technologies like prevention of insect-induced mycotoxin accumulation (Abbas et al. 2013). A meta-study merging data from 147 original studies emphasise an increase in yield in GM crops by $22 \%$ that is entirely attributed to change in pest management (Klümper and Qaim 2014). On a global scale, the Food Agriculture Organization (FAO) statistics showed no difference between maize yields of GM-growing Midwest and GMfree EU areas for the past 20 years (Heinemann et al. 2014; FOA 2015). This suggests that GM advantages reside mainly in keeping yields stable. GM crop advantages are tightly linked with the agronomic, socioeconomic and environmental context in which the crop is deployed (Russell 2008).

Swiss farming systems show some particular features that are important to consider when modelling GM's impact on sustainability. Swiss farms are in average 18 ha in size, and one third is located in mountains (FOA 2014). In addition, about $12 \%$ of farms are certified according to the Ordinance on Organic Farming, and almost all other farms produce under relatively strict cross compliance requirements (FOA 2014). In fact, another $80 \%$ of the farmers are bound to integrated production systems or other labelling systems that ban the use of GM crops. This represents well the high-quality standards required by the Swiss public and frames many of the existing regulatory aspects: the law on genetic engineering or the strict regulation on pesticides that apply in Switzerland. The extent to which GM crops may sustain Swiss agriculture remains to be shown. Anticipating a possible end of the moratorium (theoretically at the end of 2017), assessment of feasibility to build a distinct pipeline for GMderived food, referred to as "coexistence" has been performed (Albisser Vögeli et al. 2011). Taking advantage from the existing segregation between organic and conventional productions (i.e. non-organic and non-integrated), the challenges are to build a "GM-specific" pipeline. A large research effort has been performed to draw safety, legal and technical guidelines (Albisser Vögeli et al. 2011).

To evaluate the impact of GM crops on Swiss agrosystems, we analysed the impact of four crops that are critical for Swiss agriculture (reviewed in details in Speiser et al. 2013). We first focussed on two GM crops already on the market: an insecticide-producing (Bt) maize resistant to the European corn borer (Ostrinia nubilalis) and corn rootworm (Diabrotica virgifera) and an HT sugar beet (Table 1). In addition, we analysed two crops that are not yet commercially available but may be more adapted to the Swiss agricultural context: a potato variety resistant to late blight (Phytophtora infestans), (Fig. 1) based on a $\mathrm{R}$ gene (Jo et al. 2014) 
Table 1 Description of scenarios analysed by the MCDA model

\begin{tabular}{ll}
\hline Selected crops & Scenario \\
\hline Bt maize $^{\mathrm{a}}$ & A. flow of goods segregation + Trichogramma \\
Bt maize $^{\mathrm{a}}$ & B. no flow segregation + Trichogramma \\
Bt maize & C. flow of goods segregation + insecticide \\
HT sugar beet $^{\mathrm{b}}$ & A. low weed pressure \\
HT sugar beet $^{\mathrm{b}}$ & B. high weed pressure \\
FR potatoes $^{\mathrm{c}}$ & Average late blight infection \\
FR BR apple $^{\mathrm{d}}$ & Average scab and fire blight infections \\
\hline
\end{tabular}

$B t$ expressing the Bt insecticide toxin, $H T$ herbicide tolerant (here glyphosate), $F R$ fungi resistant, $B R$ bacteria resistant

${ }^{a}$ For maize scenarios, two parameters were tested in parallel: contribution to sustainability of GM crop on fluxes outside the farm, downstream flow of goods and coexistence (A vs B) or comparison of various strategies aiming at limiting pests (A vs C). Noteworthy, it is expected no Trichogramma to be used in Bt maize in A and B scenarios (as resistant to the lepidopteran). Similar levels of fertilisers, watering, weeding and soil preparation were postulated across the three scenarios for GM and conventional crops. Application of synthetic insecticide in scenario $\mathrm{C}$ is under derogatory regime only (for example, indoxacarb or spinosad)

${ }^{b}$ No differences in crop management between conventional and GM sugar beet: Similar levels of fertilisers, watering, weeding and soil preparation were postulated across the two scenarios. Herbicides (cocktail of triazines and benzofuranes) are applied three times for conventional sugar beet (with a different timing depending on the level of weeds (Avs B) and two times for glyphosate on HT sugar beet. Note that no-till cultivation is possible in Swizerland but not implemented in these two scenarios

${ }^{\mathrm{c}}$ The amounts of fungicides applied in conventional potato culture to palliate Phytophtora infection are varying a lot depending on the climatic condition and the variety of potato used (f. ex. "Fortuna" could be used as GM variety and compared to "Agria," the most commonly used variety in Switzerland for conventional culture, Speiser et al. 2013). It is postulated here that fungicides were only used for conventional varieties and against a single mild infection during the entire cultivation process. Practical segregations of flow of goods for conventional and GM potatoes are in place according to coexistence rules

${ }^{\mathrm{d}} \mathrm{BR}$ and FR traits are postulated to be introgressed into the popular variety "Gala" and compared to the conventional Gala. Fungicide and antibiotics spraying were reduced but not removed entirely in the GM scenario. Noteworthy, no additional costs were applied in the model to the BR FR apple variety, as generated free of any intellectual property rights by public donation

and an apple resistant to scab (Venturia inaequalis), (Fig. 1) by introgression of the gene Rvi6 and to fire blight (Erwinia amylovora) by introgression of the gene FB MR5 (Vanblaere et al. 2011).

In this study, using both literature review and stakeholder interviews, we aimed at assessing the costs and benefits of the four GM crop models that may be relevant to the Swiss agrosystem. We combined both environmental and socio-economic data in an ex ante multicriteria decision analysis (MCDA) model using the DEXi software (Bohanec et al. 2008; Bohanec et al. 2013) and tested the sustainability of various scenarios containing GM crops or not (Table 1).

\section{Methodology used for assessing sustainability of Swiss agrosystems}

\subsection{Qualitative multi-criteria decision analysis using MCDA}

MCDAs are well suited for assessing complex multidimensional concepts such as sustainability (Sadok et al. 2009). In this work, we used a model produced using the DEXi software, already used for economic and ecological assessment of Bt maize in various crop systems (Bohanec et al. 2008; Pelzer et al. 2012; Bohanec et al. 2013). To build the model, we first gathered a list of attributes that were the most representative of each portion of either the socioeconomic or environmental sustainability (Figs. 2 and 3). Sustainability of agrosystems is often divided in two or three dimensions: environmental, social and economic (Lichtfouse et al. 2009; Mouron et al. 2012). We choose here to gather social and economic aspects together in order to best reflect their strong interdependency in Swiss agrosystems (Bonfadelli et al. 2007). The overall socio-economic sustainability was divided in 21 attributes representing the three major stakeholders in agriculture: sustainability for farmers, agribusinesses and consumers (Fig. 2). Socio-economic sustainability is aiming at preserving the prosperity of all the agricultural actors as well as participating in their integration to the society (Swiss Federal Council 2016). Environmental sustainability aims at a responsible and efficient use of habitats and resources needed for the agriculture (Swiss Federal Council 2016). Environmental sustainability was divided in 22 attributes grouped in three main categories: biodiversity, environmental quality and resources use (Fig. 3). A specific focus on the pressure on resources and impacts on biodiversity in the evaluation of the environmental sustainability has been performed, again reflecting the very specific characteristics of the Swiss cropping systems (Speiser et al. 2013). A definition of each attribute is given in Tables 2 and 3. Noteworthy, the definition of each attribute and the structure of the tree itself have been validated by stakeholders representative of each of the six branches involved: consumer's associations, farmer's syndicates, industry representative, NGOs, scientists from several Swiss scientific organisms: the Swiss Science Academia, Agroscope and the Research Institute of Organic Agriculture (see Acknowledgements for exact list of stakeholders involved).

\subsection{Definition of the model components}

Our comparative model used a five-tier system to compare GM to baseline conventional crop systems. This scale ranks from "much lower, lower, similar, higher and much higher" 
Table 2 List of socio-economic criteria used for implementing the model and values in seven different systems

Socio-economic sustainability

Farmers

Yield

Market price

Production costs

Labour costs

Farmer eco. independency

Local acceptance

Agricultural practices

Agribusiness

Innovation

Seed selection

Pesticides/fertilisers

Products flux separation

Output markets

Food chain supply

Control firms

Economic independency

Effects on SME

Image of agribusiness

Consumers

Freedom of choice

Impact on health

Public acceptance

Buying price
Represents the marketable yields compared between GM and conventional (non-GM) lines. It takes into account a combination between theoretical yield and potential yield reduction. This parameter is linked to production costs (Bock et al. 2002; Gomez-Barbero et al. 2008; Albisser Vögeli et al. 2011; Brookes and Barfoot 2013; Nichterlein et al. 2013; Speiser et al. 2013)

Market price parameter is linked mostly to public acceptance and costs linked to coexistence and labelling

Production costs including seeds' price, fertilisers, pesticides, diesel and equipment, watering, costs induced by coexistence: insurances, testing (Albisser-Vögeli et al. 2011). Higher costs are implying lower sustainability of this attribute

Evaluation in working $\mathrm{h} / \mathrm{ha}$

Refers to Swiss Constitutional right (Art. 26 and 27). The more the farmer is free to choose a crop system, the better his independence is (Demont and Devos 2008)

Impact of GM use on local farming systems and other derivatives (f. ex. honey production, Abrol 2012)

Influences of new agrosystems on a traditional and social scale. Includes also interactions/help between farmers

Summarise capacity to develop new products or methods to increase sustainability of agrosystems or profitability

Potential advantage of GM seeds on Swiss breeders, seed market and adaptation to new purity standards according to coexistence rules

Influence of GM use on crop protection market (quantity of substances sold, necessary new regulations)

Costs linked to separation of good depending on coexistence regimes (transport, distances, storing capacities, education and quality controls) (Menrad et al. 2009; Albisser Vögeli et al. 2011)

Output markets mainly for food products and their derivatives (i.e. sugar for sugar beet, starch for maize, or potatoes). This parameter is linked to consumer demand (Aerni et al. 2011)

Influence of GM introduction to import for the relative crops. It is assumed that no changes in processing exist between products originating from GM or non-GM crops

Influence of coexistence on firms involved in quality and purity controls. Maintaining a coexistence regime will induce additional controls and have an impact on the firms turnover and depends also on the purity thresholds defined by the coexistence legal framework

Consequences of GM culture on freedom of choice and decision of agro-companies.

Impact of GM use on small- and medium-sized enterprises (f. ex. equipment retailers, transforming business, milling industry)

Impact of GM use on perception of agribusiness. Swiss identity and exclusivity plays an important role in this parameter. This attribute is specific to the image of Swiss products and does not include image of Swiss farmers in the society

Possibility of choosing which product to buy. This includes also labelling standards and thresholds definition (Aerni et al. 2011; Bonfadelli et al. 2007)

Potential impact of the GM on food quality and indirectly on health (f. ex. mycotoxin reduction, Meissle et al. 2011)

Consumer opinion on GM food. Based on polls and opinion studies (Aerni et al. 2011; FOA 2015)

Variation of prices tightly linked to public acceptance and premium (labels...) linked to crop system used (Price et al. 2003)

All parameters were comparing GM with a conventional cropping system (defined as non-organic and non-integrated cultural systems). Literature references that helped to define the attributes are in brackets

sustainability in the GM system compared to the conventional system. For the second and third degree of aggregation, two additional tiers were added to keep sufficient resolution according to DEXi guidelines (Bohanec et al. 2008). Once the branching system has been established, various weights for each branches have been assigned according to experts and literature data (Bohanec et al. 2008; Pelzer et al. 2012; Mouron et al. 2012). All the weighing parameters for each 
Table 3 List of environmental criteria used for implementing the model and values in seven different systems

Environmental sustainability

Biodiversity

Protected species

Genetic flow

Persistence

Pollinators

Biological control systems

Soil ecosystem

Water ecosystem

Environmental quality (pressures on the environment)

$\mathrm{CO}_{2}$ emissions

$\mathrm{N}_{2} \mathrm{O}$ emissions

$\mathrm{NH}_{3}$

Fertiliser volatilisation

Diesel and $\mathrm{NO}_{2}$

Pesticide run-offs

Fertiliser run-offs

Erosion risks

Compaction risks

Pesticide residues

Resources use

Water use

Energy use
Effect of GM crops over conventional system on species that are present in fields in large quantities and/or dependent on agriculture. It gathers mammals, birds, amphibian, reptiles, insects, plants, mosses, fungi and microorganisms (Geiger et al. 2010; Speiser et al. 2013)

Probability of gene transfer from GM to wild relatives. Horizontal gene transfer is not considered (f. ex. to bacteria) (Bartsch and Schmidt 1997; Reim et al. 2006; Demont and Devos 2008; Granado et al. 2008; Speiser et al. 2013; Melé et al. 2015)

Influence of transgene(s) on crop invasiveness. It can be associated to additional coexistence measure aiming to avoid GM spread (Sweet and Bartsch 2012)

Influence of GM use and changes in cropping system on wild and honey bees. Evaluation of toxicity on pollinators based on the Pesticide Property Database (Haughton et al. 2003; Hertfordshire 2015) (PPDB 2013)

Influence of GM use on biological pest-control systems (f. ex. arthropods, entomopathogenic fungi). Direct impact of the molecule produced by the $\mathrm{GM}$ or indirect impact due to the changes in agricultural practices are evaluated (Raudonis et al. 2004; Bigler and Albajes 2011)

Influence of GM use on soil ecosystems. This parameter does not include soil pollution (taken into account in the environment quality section) (Turrini et al. 2005; Bünemann et al. 2006; Icoz and Stotzky 2008)

Influence of GM use on water ecosystems. This parameter does not include water pollution (taken into account in the environment quality section) (Wertz et al. 2007; Wolt and Peterson 2010)

Influence of GM use on $\mathrm{CO}_{2}$ emission. Mostly due to fuel consumption at any step of the crop production (field, transport). Strongly dependent on the coexistence regime (Albisser-Vögeli et al. 2011)

Influence of GM use on $\mathrm{N}_{2} \mathrm{O}$ emissions. Mostly due to fertiliser volatilisation Influence of GM use on ammonium release (mostly originating from fertilisers)

Influence of GM use on nitrogen volatilisation when fertilisers are spread

Influence of GM use on particular matters, fuel particles and $\mathrm{NO}_{2}$ emission. Mostly due to fuel consumption at any step of the crop production (field, transport). Strongly dependent on the coexistence regime (Albisser-Vögeli et al. 2011)

Influence of GM use on pesticide run-offs into groundwater

Influence of GM use on fertiliser run-offs into groundwater

Influence of GM use on erosion risks. For example, no-till farming strategies often associated with HT crops even if not considered here (Steinbach and Alvarez 2006; Soane et al. 2012). Minimum till is often preferred in Switzerland.

Influence of GM use on soil compaction. Linked to variation in crop managements (Steinbach and Alvarez 2006; Soane et al. 2012)

Influence of GM use on pesticide residues. Linked to variation in crop managements. Pesticide toxicity has been assessed based on the Pesticide Property Database (PPDB 2013)

Influence of GM use on water use. Does not include indirect water needs for agrochemical production like fertilisers. Swiss agriculture has been confronted to some water limitation issues in the recent years

Influence of GM use on energy needs for cultivation and downstream costs linked to coexistence. This attribute includes transport to and from the field, flows of products and energy needed to run a separate pipeline of goods (in the case of coexistence) 
Table 3 (continued)

Environmental sustainability

Land use

Fertiliser use

Pesticide use
Influence of GM use on land use. Related to variation of yields per hectare of land. Variation in density of crops and rotation may influence this attribute

Influence of GM use on the quantity of fertiliser (and each individual components of them) used for a similar yield expected. Micronutrients were also taken into consideration

Influence of GM use on the quantity of active substances used for crops. For example, variations in herbicide use in HT, insecticides in Bt, fungicide in FR are expected

All parameters were comparing GM with a conventional cropping system. Literature references that helped to define the attributes are in brackets $B t$ expressing the $B t$ insecticide toxin, $H T$ herbicide tolerant (here glyphosate), $F R$ fungi resistant, $B R$ bacteria resistant

attribute are summarised on the model structure (Figs. 2 and 3). An extensive description of agrosystems using GM maize, potatoes and apple trees in a Swiss context was used as a baseline model previous to stakeholders/expert's consultations (Speiser et al. 2013). Next, all the weights of the attributes and relative aggregation rules have been adapted according to experts and
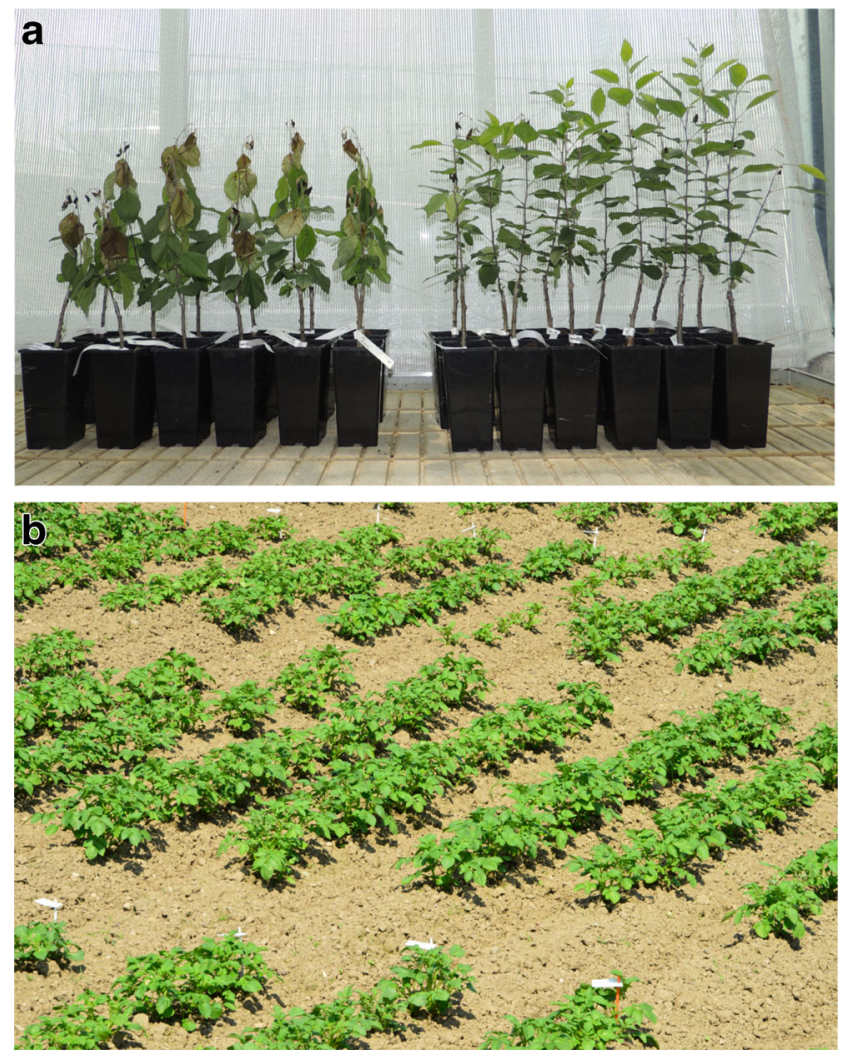

Fig. 1 Two prototypal cis-genic crops tested in switzerland. a. Gala apple trees (left) and cis-genic resistant to fire blight (right) by expression of $\mathrm{Fb}$ MR 5 in a confined greenhouse expirement. b. cis-genic potatoes resistant to late blight by expression of an $\mathrm{R}$ gene in a field experiment on the Agroscope Protected site (www.protectedsite.ch). Photos are courtesy from Agroscope Reckenholz. Switzerland literature data. Generally, we aim at keeping a rather neutral point of view by averaging most of aggregated attributes as previously described (Bohanec et al. 2008). Changes depending on the model's user could be performed (for example, the perspectives or aims of a farmer may be different from other stakeholders). Some particular attributes follow specific rules based on literature data: for example, air quality was constituted of $50 \%$ greenhouse gas (30\% $\mathrm{CO}_{2}+\mathrm{N}_{2} \mathrm{O}$ and $20 \%$ diesel particles), $30 \% \mathrm{NH}_{3}$ and $20 \%$ pesticide volatilisation (Pelzer et al. 2012). In total, 43 basic parameters were used to compare differential sustainability between GM and non-GM scenarios for the four crops studied. Building the model was performed previous to the evaluation step, and the model kept similar for all scenarios.

\subsection{System boundaries}

Due to the limitation of studying hypothetical "ex ante" scenarios, we define the three main aspects that limit the GM/non-GM comparison. Firstly, the amounts of subsidies (direct payments) were postulated as similar for GM crops as for conventional ones. Secondly, the appearance of weeds tolerant to HT plants (Brookes and Barfoot 2013; Green 2014), insect resistance for Bt species, apple scab, or fire blight resistances were not monitored here despite their reported occurrence (Vogt et al. 2013; Fahrentrapp et al. 2013; Jin et al. 2015) but were nonetheless discussed. MCDA and more generally multiattribute models are not directly suitable for time-series evaluation (Bohanec et al. 2008). Thirdly, potential savings originating from a decrease in crop import on a country scale were not considered.

\subsection{Comparison of seven cropping systems containing GMO or not}

Seven pairwise comparisons from four species were made: three scenarios for comparing Bt vs. conventional maize, two scenarios comparing HT vs. conventional 


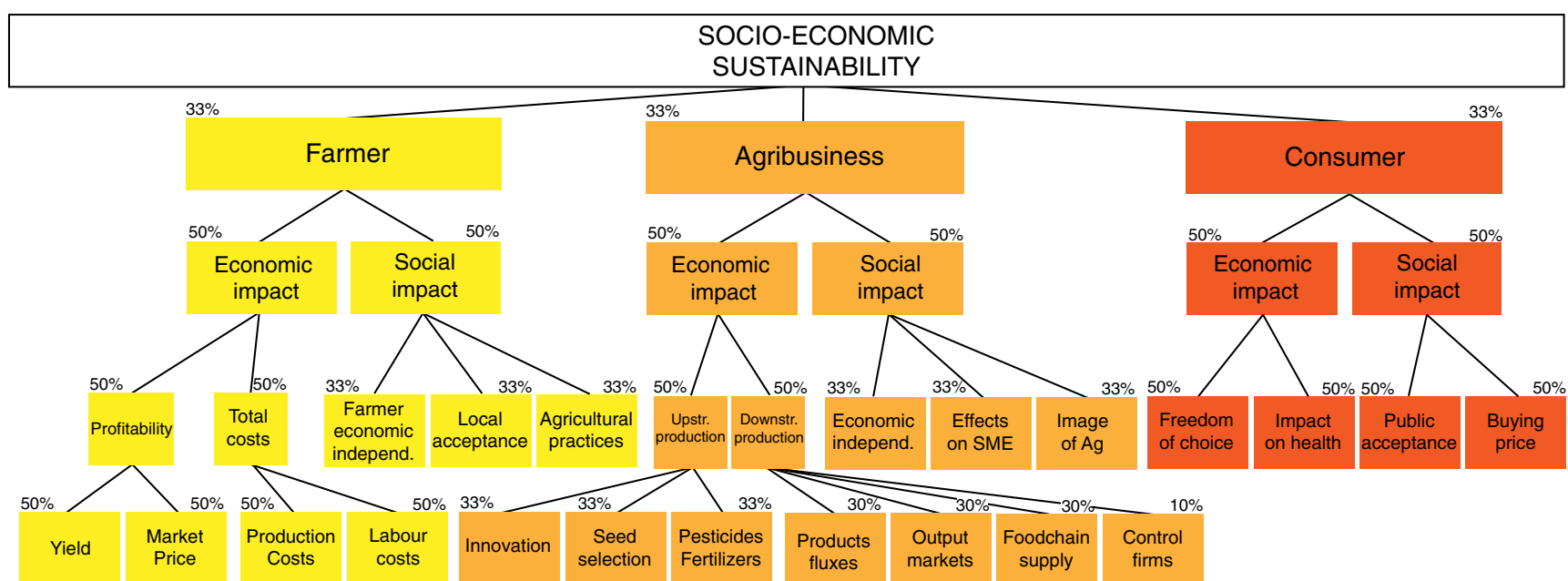

Fig. 2 Structure of the MCDA model tree used for scoring socio-economic sustainability of Gm crops used compared to conventional crops. Three main stakeholders were assessed: farmers (yellow), agribusiness (orange) and consumer (red). Percentages are weights for aggregating the attributers

sugar beet, one scenario comparing conventional and fungiresistant (FR) potatoes and finally one scenario comparing conventional with FR and bacterial-resistant (BR) apple trees (Table 1). These crops were chosen as a representative panel of what is or may come onto the market in the next future. The three different scenarios in maize allowed us to compare sustainability when using biological control agents and when costs linked to coexistence were taken into accounts. Scenario A and B assumed that biological control techniques were performed by applying the parasitoid wasp Trichogramma spp. against the European corn borer (O. nubilalis), whose efficiency can be similar to insecticides under optimal conditions (Meissle et al. 2011). In scenario C, wasps were replaced by insecticide spraying like spinosines or carbamates (authorised only under a derogatory regime against $O$. nubilalis in Switzerland). In addition, scenarios $\mathrm{A}$ and $\mathrm{C}$ take into account costs of coexistence, while $\mathrm{B}$ considers all maize produced to stay on the farm to be used as feed, therefore avoiding any need for harvest separation (Table 1). All values from various decision alternatives (scenarios) are summarised in Table 4. Again, those were defined in collaboration with the stakeholders (see Section 2.1 and Acknowledgements)

Yield in sugar beet cultivation is highly dependent on weed control (Nichterlein et al. 2013). Therefore, two scenarios were tested with the HT sugar beet, one with a low weed pressure (scenario A) and the other with a high weed pressure (scenario B) (Table 1).

For the sake of clarity and as neither FR potato nor FR BR apples are available yet, only one scenario was tested for each of these species. All attributes chosen to fill the model were given a score (Table 4), by answering the question whether using the GM cultivar was better or worse than its conventional counterpart according to the defined scale. Data were processed by DEXi software and radar plots generated to represent the sustainability for each of the six main components of the model (farmer,

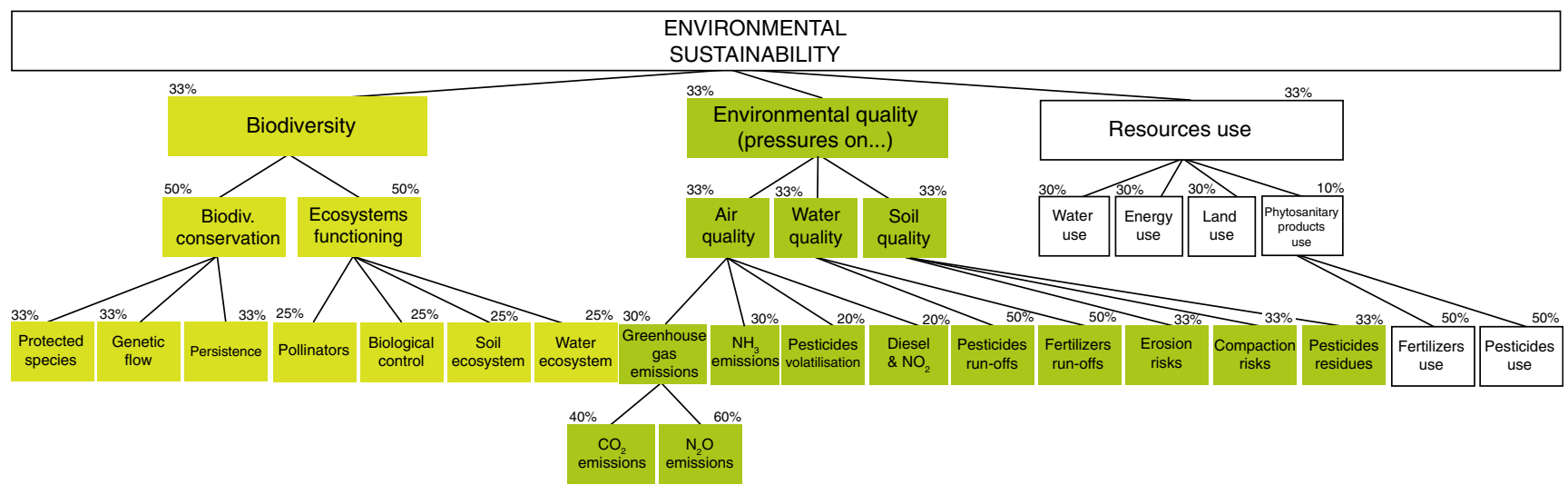

Fig. 3 Structure of the MCDA model tree used for environmental sustainability of GM crops used compared to conventional crops. Three main aspects were taken into consideration: biodiversity (light green), environmental quality (green) and resources use (white). Percentages are weights use for aggregating the attributes 
Table 4 Parameters used for the evaluation of seven GM-containing cropping systems and comparison with each of their conventional (non-GM) counterpart

Bt maize A Bt maize B Bt maize C HT sugar beet A HT sugar beet B FR potato FR BR apple

Socio-economic sustainability

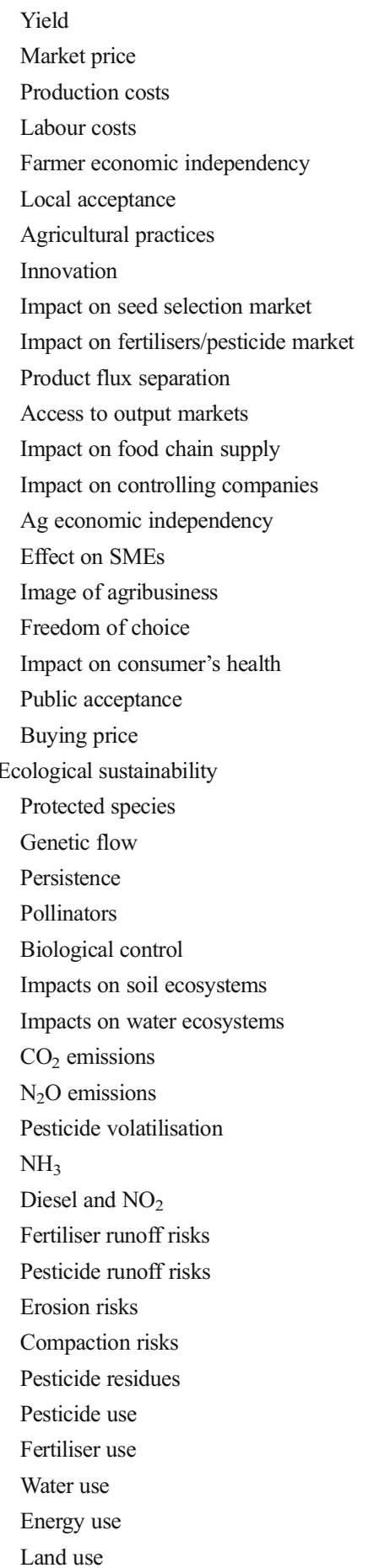

$\begin{array}{ll}0 & 0 \\ -1 & 0 \\ -1 & 1 \\ -1 & -1 \\ 1 & 1 \\ -1 & -1 \\ 0 & 0 \\ 1 & 1 \\ -1 & -1 \\ 0 & 0 \\ -2 & 0 \\ -1 & 0 \\ 0 & 0 \\ 1 & 1 \\ 0 & 0 \\ -1 & 0 \\ -1 & -1 \\ 1 & 0 \\ 0 & 0 \\ -1 & 0 \\ -1 & 0 \\ & \end{array}$

1

$-1$

$-1$

$-1$

1

$-1$

0

1

$-1$

$-1$

$-2$

$-1$

0

1

0

$-1$

$-1$

1

0

$-1$

$-1$

$0 \quad 0$

$0 \quad 0$

0

0

0
0

0

0

$-1$

0

0

0

$-1$

$$
0
$$$$
0
$$$$
0
$$$$
0
$$$$
1
$$$$
0
$$$$
0
$$$$
-1
$$

0

$\begin{array}{ll}1 & 1 \\ -1 & \\ 1 & 1 \\ 0 & \\ 1 & \\ -1 & 1 \\ -1 & -1 \\ 1 & -1 \\ 0 & \\ -1 & \\ -2 & \\ -1 & -1 \\ 0 & -1 \\ 1 & \\ 0 & -1 \\ -1 & -2 \\ -2 & \\ 1 & \\ 0 & \\ -2 & \\ -1 & -1 \\ & \end{array}$

$\begin{array}{lll}1 & 0 & 0 \\ -1 & -1 & 0 \\ 1 & -1 & 0 \\ 0 & 0 & 0 \\ 1 & 1 & 1 \\ -1 & -1 & -1 \\ -1 & 0 & -1 \\ 1 & 1 & 1 \\ 0 & 0 & 0 \\ -1 & -1 & -1 \\ -2 & -2 & 0 \\ -1 & -1 & -1 \\ 0 & 0 & 0 \\ 1 & 1 & 1 \\ 0 & 0 & 0 \\ -1 & -1 & 0 \\ -2 & -1 & -1 \\ 1 & 1 & 1 \\ 0 & 0 & 0 \\ -2 & -1 & -1 \\ -1 & -1 & -1\end{array}$

$-1$

0

0

$-1$

$-1$

0

0

0
1

1
0

0
0

0
0

0
1

1
0

0
1

1
0

0
1

1
0

0
1

1
0

0
0
-2

Land use

A scale using five grades was used: -2 , much lower; -1 , lower; 0 , similar; 1 , higher; and 2, much higher sustainability. Scenarios are described in Table 1. Scoring of each attribute has been determined according to published data and results from experts' workshops (see Tables 2 and 3 for attribute definitions)

$B t$ expressing the $B t$ insecticide toxin, $H T$ herbicide tolerant (here glyphosate), $F R$ fungi resistant, $B R$ bacteria resistant 
agribusiness, consumer, biodiversity, environmental quality, resources use).

\section{Effects of GM crops on sustainability of agrosystems}

\subsection{GM crops lead to an overall lower socio-economic sustainability}

Three main actors of the socio-economic sustainability were described in the model: farmers, agribusiness and consumers. Socio-economic sustainability is at best similar to the conventional crop for all actors in scenario B of the Bt maize (Fig. 4). Consumer sustainability scores were mostly lower in GM systems (Figs. 4, 5 and 6). This is mainly due to low acceptance of any of the four GM crops. In addition, for all scenarios except when produced crops aimed at consumption on site for feed (maize scenario B) and therefore do not impact downstream fluxes. The attribute representing projected buying prices was overall less sustainable (i.e. lower buying price). This took into account coexistence costs in addition to the exclusion of GM's from most labels. Agribusiness companies performed mostly worse when GM were used, except in the case of Bt maize scenario B and FR BR apple (Figs. $4 \mathrm{~b}$ and $6 \mathrm{~b}$ ). The pattern of sustainability between maize scenarios was similar when considering steps downstream of production ( $\mathrm{A}$ and $\mathrm{B}$ ), independent of the use of biological controls (Fig. 4). The Swiss fresh apple market already uses a strict labelling of the products; therefore, introduction of the FR BR apple variety does not have a strong negative influence on downstream fluxes: Small- and medium-sized enterprises (SMEs) would not need to adapt their existing production pipeline. For FR potatoes (Fig. 6a), socio-economic sustainability is low and would be highly dependent on the GM cultivar used.

Farmers would not profit from introduction of GM crops mostly due to (1) low public acceptance leading to uncertainties for a viable market for GM products, (2) decrease in their liberty of freedom induced by a tighter integration into the agribusiness chain. Indeed, choice of a defined HT crop links the farmer to use one specific herbicide (Speiser et al. 2013). (3) Management advantages do not compensate biotech premium for seed price. Predictions about yield improvements were largely variable depending on the source. For example, the HT sugar beet yield increases range from none to $18 \%$ depending on the study (Brookes and Barfoot 2013; Nichterlein et al. 2013). No significant increase in yield of Bt maize,
Bt maize vs conv. maize.

a Scenario A Consumer

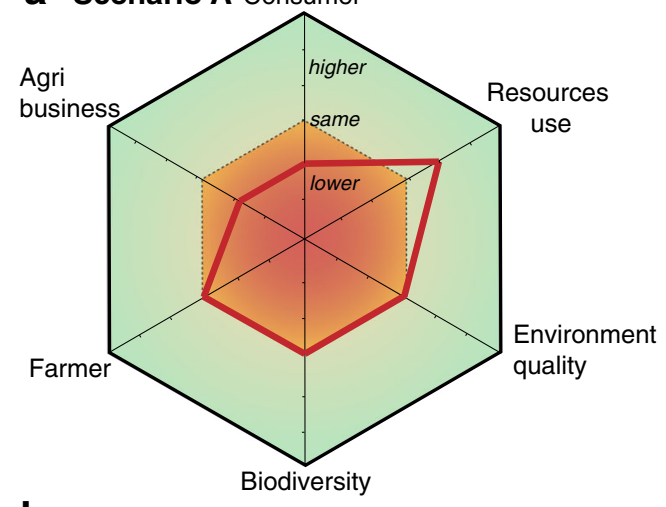

b Scenario $\mathbf{B}$ Consumer

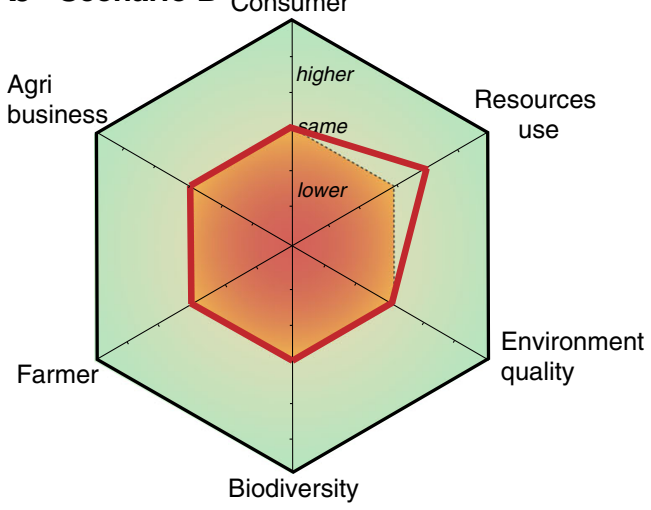

C Scenario C

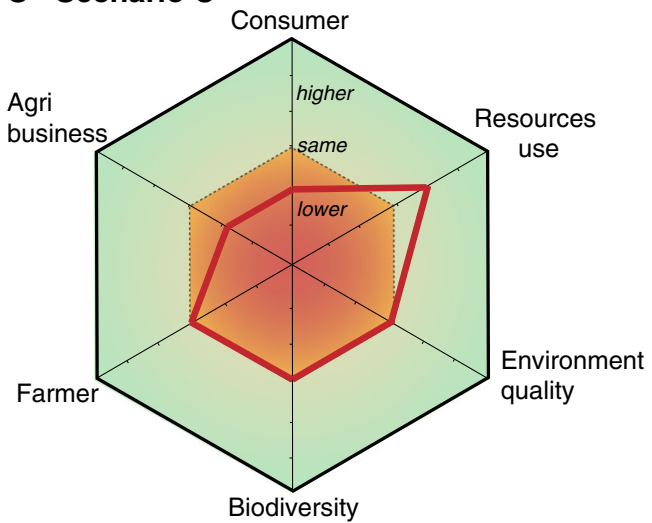

Fig. 4 Evaluation of socio-economic (farmers, agribusiness and consumers) and environmental (resources use, environmental quality and biodiversity) sustainability when Bt maize is compared to conventional maiz. Three scenarios A, B and C were projected (see Table 1 for details). Secnarios $\mathrm{A}$ and $\mathrm{C}$ include consequences of coexistence measures with or without biocontrols by Trichogramma respectively. Scenario B represents durability without flows of good outside the farm and pest's biocontrol. Red lines figured sustainability for each of the six attributes. Higher (green) or lower sustainability levels (red) are plotted for each of the six attributes according to the outputs from the DEXi software

FR BR apple, or FR potato were expected or modelled (Speiser et al. 2013). However, all sources were consistent with a decrease in selling price originating from premium on GM seed prices and 
HT sugar beet vs conv. sugar beet

a Scenario A Consumer

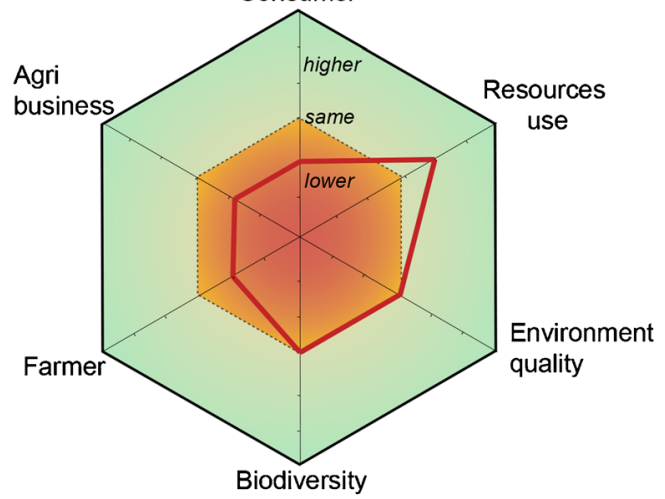

\section{b Scenario B}

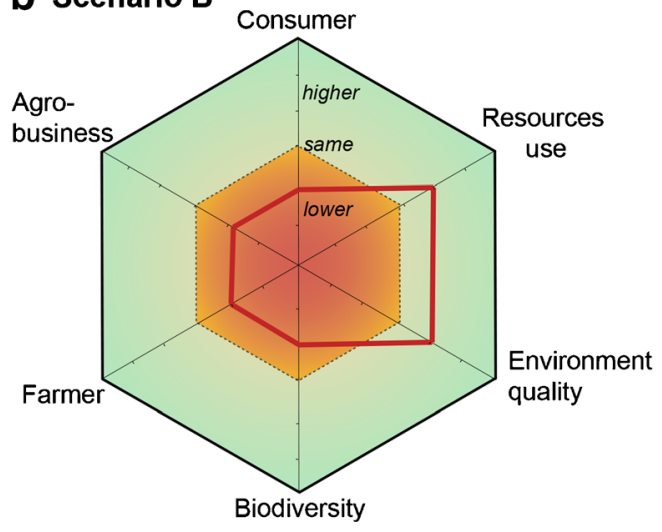

Fig. 5 Evaluation of socio-economic (farmers, agribusiness and consumers) and environmental (resources use, environment quality and biodiversity) sustainability when $\mathrm{Ht}$ sugar beet is compared to conventalal sugar beet. Two scenarios A and B were projected Scenario A represents a mild adventices pressure whereas scenario B a stong adventice pressure that implies additional herbicide treatments (see Table 1 for details). Red line figures sustainability for each of the six attributes. Higher (green) or lower sustainability (red) levels are plotted for each of the six attributes according to the results of the DEXi software

additional costs for coexistence measurements (Kohler 2005). Labelling of non-GM products is generally considered to be a niche market by agribusiness and consumer representatives that may be associated with relatively higher prices for GM-free products.

\subsection{Sensitivity analysis postulating high GM acceptance shows variations in sustainability}

It appears that the GM crops implemented in our model are unlikely to bring short-term socio-economic sustainability in the Swiss context. If global acceptance of GM crops or modification of their legal status were to be foreseen, it is very likely that the entire socioeconomic sustainability would become positive. To validate our model, we performed a sensitivity analysis by hypothesising a very high acceptance of GM in both

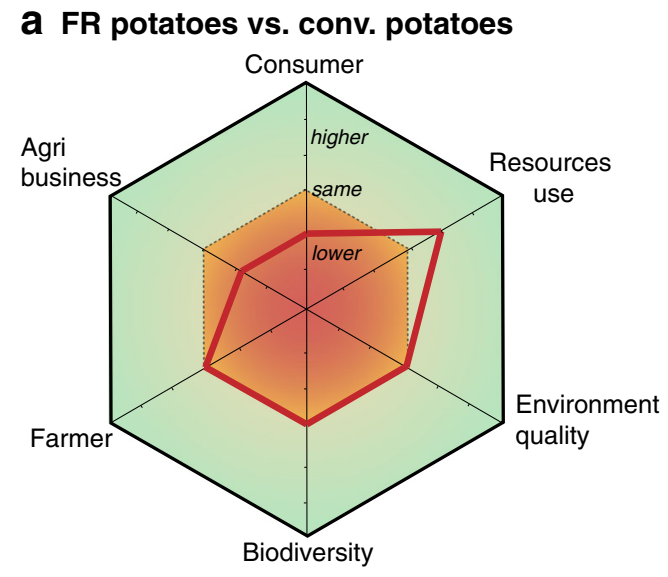

b FR-BR apple vs. conv. apple

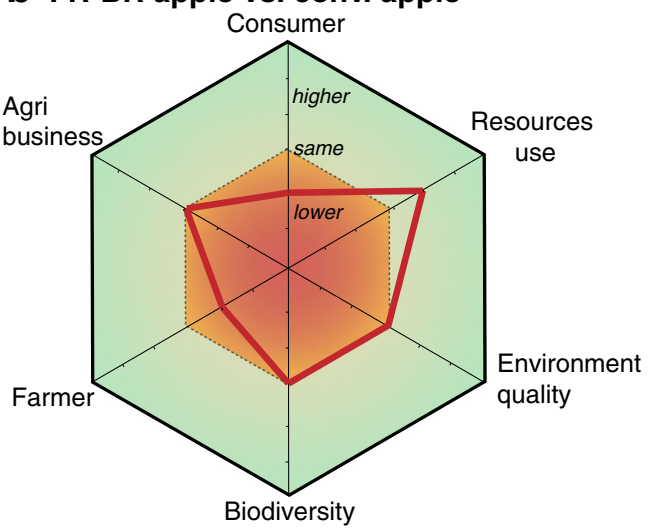

Fig. 6 Evaluation of socio-economic (farmers, agribusiness and consumers) and environmental (resources use, environment quality and biodiversity) sustainability when FR potato BR «Gala» apple are compared to conventional varieties with average infections of late blight and scab+fire blight respectively. Red line figures sustainability for each of the six attributes. Higher (green) or lower sustainability levels (red) are plotted for each of the six attributes according to the DEXi results.

consumers and farmers. Under these conditions, $\mathrm{Bt}$ maize and FR potato crops become more advantageous for farmers than their conventional counterparts making them more likely to be used (Fig. 7). However, modelled socio-economic benefits for agribusinesses and consumers were marginal (Fig. 7).

\subsection{GM crops marginally improve environmental sustainability}

In parallel to socio-economic dimensions, attributes associated with environmental sustainability were assessed. The most positive impact of the use of any of the four GM lines tested is observed on the resources use (Figs. 4, 5 and 6). Varietal resistance against pests and disease are useful traits that reduce pesticide use as well as contribute to stabilise yields (Jo et al. 2014; Krens et al. 2015; Jacobsen et al. 2015). For example, BR apple cultivation is projected to reduce fire blight symptoms down to levels observed in naturally resistant 
Fig. 7 Hypothetical influence of high acceptance for GM crops on sustainability. Test of the sensitivity of the model setting parameters "public acceptance" and "local acceptance" to "much higher". The scenarios presented are the same as in Fig 3-4-5. Grey: baseline (as in Figure 3, 4 and 5), red: the new sustainability levels. a Bt maize vs conv. maize. Scenario A

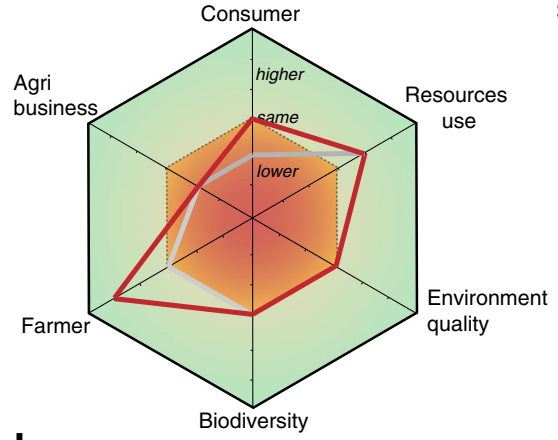

b Scenario B

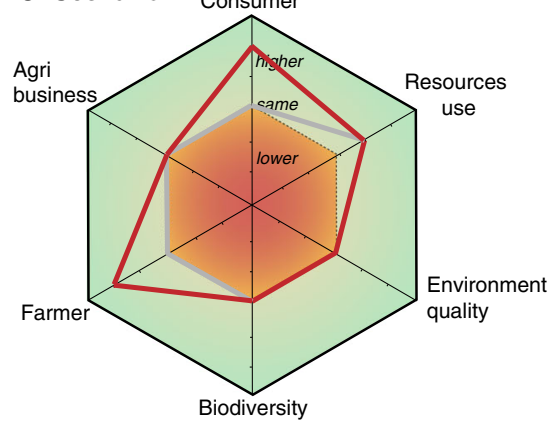

C Scenario C

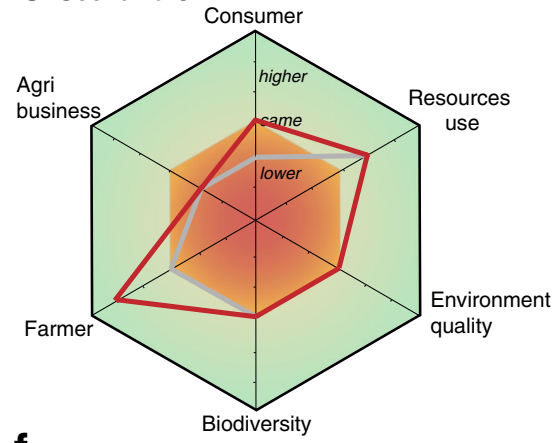

f FR potatoes vs. conv. potatoes

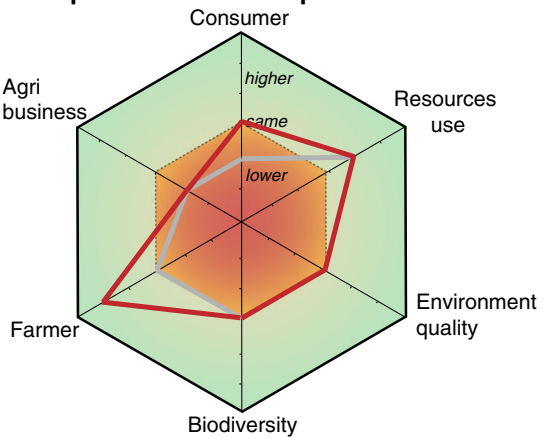

d HT sugar beet $v s$ conv. sugar beet Scenario A Consumer

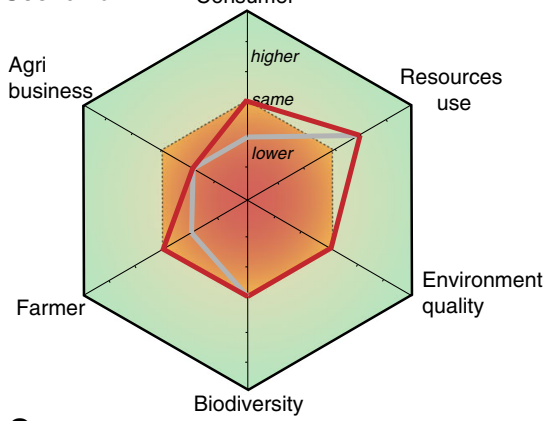

e HT sugar beet. Scenario B

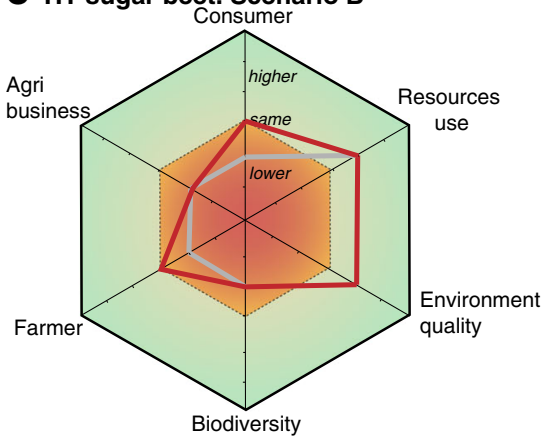

Sensitivity analysis:

- High GMO acceptance

- Baseline GMO acceptance

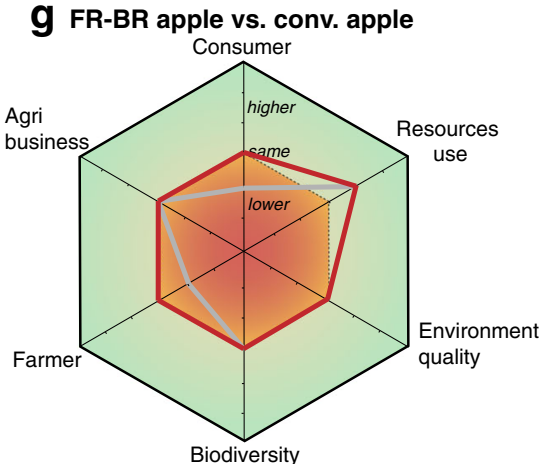

Malus robusta (at least $75 \%$ less infection, Gusberti et al. 2015), therefore significantly reducing the need for bactericide substances applied. Cultivation of GM sugar beet is expected to shift pesticide consumption from 4 to $2 \mathrm{~kg}$ active substance/ha in low-weed scenario $\mathrm{A}$ and 5 to $2 \mathrm{~kg} / \mathrm{ha}$ in high weed scenario $\mathrm{B}$, respectively (Nichterlein et al. 2013). In four of the scenarios, impact on energy use was consistently linked with additional costs to allow and maintain coexistence of distinct crop regimes (Figs. 4, 5 and 6). In addition, HT and Bt systems are known to favour less labourintensive crop management allowing less pressure on resources. In particular, Bt systems allow saving of insecticides (quantity used and number of spraying), especially under strong pest pressure and proper crop management, like use of natural refuge strategies (Jin et al. 2015). However, 
strong corn borer pressure is unlikely to happen for maize in Swiss agronomic systems (Hütter et al. 2000).

Less labour-intensive management also implies substantial positive impacts on parameters representing the environmental quality (Figs. 4, 5 and 6). Improvements were made concerning soil quality, soil erosion as well as savings on fuel consumption. However, no-till strategies that are often performed together with HT crops not only limit machinery usage (and therefore fuel consumption) and soil runoffs but can also increase $\mathrm{N}_{2} \mathrm{O}$ emissions and weed pressure, therefore limiting their positive environmental impact in the long term (Steinbach and Alvarez 2006; Soane et al. 2012). No-till strategies do not change fixation of carbon in the soil under Swiss climate (Soane et al. 2012). The HT sugar beet crop management is predicted to improve environmental quality the most, largely due to substitution of various herbicide cocktails by glyphosate (Fig. 2). Measures of coexistence were associated with increase in diesel and $\mathrm{CO}_{2}$ emissions and decreased sustainability of GM's environmental quality. The variations in crop rotation systems have been shown to have a relatively substantial impact on environmental sustainability (and marginal effect on the economic component, Speiser et al. 2013). We assumed here that the relative influence of the change in the rotations due to GM use would be minor in terms of sustainability output. Therefore, the increase in flexibility of crop management only translates into a marginal gain for farmers, especially in small or medium farm systems.

Impact of GM crop on biodiversity is complex and requires a case-by-case analysis (Figs. 4, 5 and 6). For example, Bt maize cultivation in scenarios using the parasitic wasp Trichogramma (scenarios A and B) does not seem to impact the overall biodiversity (Fig. 4). Impact of Trichogramma on non-target insects is considered as low (Babendreier et al. 2003). However, potential toxicity and exposure to the insecticide toxin Cry1Ab on 75 of the 159 lepidopteran species "considered as being of agricultural interest" have been predicted (van Frankenhuyzen 2013). Toxicity of various Bt toxins towards other non-target families of insects like Trichoptera (Rosi-Marshall et al. 2007) and neuropteran species is a matter of strong controversy (Romeis et al. 2013) and beyond the scope of this study but might be a source of concern (Lang and Vojtech 2006). One can argue that the alternative use of synthetic insecticides like indoxacarb (scenario C), known to be toxic at least for bees, birds, reptiles and fishes (Sanchez-Bayo and Hyne 2011), speaks for a decrease in pressure towards biodiversity in Bt compared to conventional systems. Nonetheless in Switzerland, use of synthetic insecticides against corn borers is rare (Albisser Vögeli et al. 2011) making deployment of Bt maize unlikely to be a reasonable option for farmers (Meissle et al. 2011). Noteworthy, secondary pests may also appear, like the western bean cutworm Striacosta albicosta, that are not affected by Cry1Ab (Zhao et al. 2011; Catarino et al. 2015).

A fairly mixed picture also emerged from the effect of HT crops on biodiversity. When growing HT sugar beet, like the glyphosate-tolerant H7-1, a unique early stage application without tillage is assumed (Strandberg and Pedersen 2002). No tilling reduces weed biomass significantly and therefore reduces biodiversity. Apparition of HT volunteers with time is strongly dependent on the crop management system used (Krato et al. 2012) and has not been considered here (see Section 4.1).

Similarly, predicted deployment of FR potato may help to reduce fungicide spraying that has deleterious effects on bird populations (Geiger et al. 2010). FR in GM potato can also be beneficial for entomopathogenic fungi that are otherwise threatened by broad-range fungicide mixtures that are applied according to conventional potato culture standards (Lagnaoui and Radcliffe 1998). Flexibility in management brought by FR BR apple at least indirectly leads to an increase in biodiversity in undergrowth and surrounding vegetation. No nontarget impacts have been shown for FR resistance (Vogler et al. 2010). It can be assumed that preventing spraying of antibiotics like streptomycin would have a comparative positive impact on bacteria despite the large resilience of orchard bacteriomes (Walsh et al. 2013). Like for the FR potato, it is expected that less fungicides could be applied compared to conventional orchards. Fungicide like mancozebe have shown to be toxic to insects like predatory thrips and mites (Bernard et al. 2004; Li et al. 2006), suggesting less pressure on those populations.

\section{Discussion}

\subsection{Distinction between short- and long-term sustainability is critical}

This ex ante analysis of GM-containing systems using a MCDA-based matrix allows setting up a quick diagnostic of the potential impact of these crops in a given socio-economic, ecological and agro-ecosystemic context (summarised in Table 5). This model is based on literature data and experts' advice and is therefore representative for the Swiss agronomic system, but the model backbone could be implemented to other countries or crops. Merging data, we structured the attributes and set scoring for each scenario accordingly, in order to inform the two main components of sustainability: socioeconomic and environmental attributes (Raymond Park et al. 2011). One obvious limitation of this strategy is taking a snapshot of a system without taking into account temporal variations that may differ in various crop rotation systems (Speiser et al. 2013). Maintaining crop rotations is crucial when aiming at a long-term sustainable crop management. For example, Bt 
Table 5 Summary of the model output concerning all seven scenarios tested

\begin{tabular}{llllllll}
\hline & Bt maize A & Bt maize B & Bt maize C & HT sugar beet A & HT sugar beet B & FR potato & FR BR apple \\
\hline $\begin{array}{l}\text { Socio-economic sustainability } \\
\text { Farmer }\end{array}$ & Medium & Medium & Medium & Med to low & Med to low & Medium & Med to low \\
$\begin{array}{l}\text { Agribusiness } \\
\text { Consumer }\end{array}$ & Med to low & Medium & Med to low & Med to low & Med to low & Med to low & Medium \\
Ecological sustainability & Med to low & Medium & Med to low & Med to low & Med to low & Med to low & Med to low \\
Biodiversity & & & & & & \\
Environmental quality (pressures) & Medium & Medium & Medium & Medium & Med to high & Medium & Medium \\
Resources use & Med to high & Med to high & Med to high & Med to high & Med to high & Med to high & Med to high \\
\hline
\end{tabular}

The six main components of the model (farmers, agribusiness, consumer, biodiversity, environmental quality and resources use were extracted, and the sustainability of every GM-containing scenario compared to the conventional non-GM equivalent was extracted according to the DEXi software outputs. Details of the scenarios are found in Table 1 and scoring in Table 4

$B t$ expressing the $B t$ insecticide toxin, $H T$ herbicide tolerant (here glyphosate), $F R$ fungi resistant, $B R$ bacteria resistant

systems, despite some recognised positive economic and environmental advantages (Hutchison et al. 2010; Lu et al. 2012; Edgerton et al. 2012), show some limitations due to apparition of resistance from target insects to Bt toxins (Tabashnik et al. 2009; Gassmann et al. 2011). Historically, these aspects have been taken into consideration very early on after Bt toxin release on fields (Tabashnik et al. 1994). Resistances from target insects can be overcome (at least temporarily) by using stacking of various toxin variants (13 different Bt proteins have been approved in corn in the USA (Meissle et al. 2011; Abbas et al. 2013), use of natural refuges (Jin et al. 2015), or increase of insecticide spraying. For HT systems, about 44 plant species from at least ten families are reported to be resistant to glyphosate (Green 2014). Resistance to fire blight in apple is thought to be a gene-to-gene relationship and therefore easily overcome by the parasite. For example, some E. amylovora strains have overcome the resistance of cultivar MR5 in a couple of years via single point mutations (Vogt et al. 2013). The complexity of host/pathogen relationship makes likely to be necessary (1) a coordinated research effort to understand mechanisms used, (2) a tailored design of resistance genes/mechanisms to be introgressed into the new GM event and finally (3) an adaptive crop management system.

Positive impact on resources use and environmental quality linked to less labour-intensive management can fade with time if increased amounts of pesticides would be necessary to compensate for resistances. However, without considering fully the reported impact of rotations (Speiser et al. 2013), very similar output could be observed throughout all the GM's scenarios tested.

\subsection{Sustainability is impacted by coexistence measures}

The onset of coexisting regimes of GM and non-GM crops has some negative impact on both socioeconomic and environmental sustainability. It is however difficult from the published data and stakeholders' consultation to determine the threshold above which it would be economically worth deploying GMs for farmers (Messean et al. 2006). In cereals, additional 5$15 \%$ costs were modelled to keep a $0.9 \%$ limit of contamination for labelling (Messean et al. 2006; Menrad et al. 2009; Albisser Vögeli et al. 2011). Similarly, a necessary increase in isolation distances for GM maize was described as a potential pitfall for the use of GMs. As seen in our analysis, other elements specific to each crop can be taken into consideration as a burden to coexistence: probe testing, necessary new product handling strategies (use of dedicated machines...). Despite an extensive research and modelling effort, scientific relevance and the eventual consequences of coexistence measures are far from being normalised in the rest of Europe (Devos et al. 2014). Strong variations in coexistence measures across member states (like isolation distances) became with time a political tool to modulate GM policy relatively independently of the state of scientific knowledge (Devos et al. 2009). Nevertheless, it is also clear that an ex ante regulatory framework that makes the coexistence a possible option in the future is necessary to help preserving consumer's freedom of choice.

\section{Conclusion}

Our study focused mostly on GM crop representatives that may be of interest for the Swiss agrosystems whether being commercially available or still in development. These are first-generation GM crops that were made mostly to bring flexibility to crop management and developed to allow an intensive and largescale farming model that is not predicted to adapt well to Swiss agrosystems. Thus, it is somehow not surprising that these particular crops (HT and Bt) do not fit well in the very specific dynamics of today's Swiss agrosystems. We evaluate here using 
a new method (MCDA) the extent to which adoption of GM crops may change the global, i.e. socio-economic and environmental sustainability of these agrosystems (Speiser et al. 2013). This provides a tool for future analyses of potential new cropping systems. From the seven scenarios studied, we conclude that without a tailored approach in GM design that responds to specific Swiss farmer and consumer needs (Baur and Nitsch 2013), new traits brought by green biotechnology have little chance to show their use or acceptance broadened. The limits of HT and Bt crop integration in the Swiss agrosystems shown in our study may point to a very restrictive view compared to the broader awaiting challenges concerning the future of green biotechnologies. In fact, despite some limited sustainability due to mainly a lack of public acceptance supported by a lack for a broad scientific consensus on their safety (Hilbeck et al. 2011; Hilbeck et al. 2015), these results encourage a local agronomic research effort coupled to robust modern plant-breeding programs (SCNAT 2013). There are multiple problems in agronomic systems that require locally adapted solutions: pest and disease control, salt and drought tolerance, heavy metal contaminations, crop quality and environmental impacts. The BR FR cis-genic apple described here or the wheat variety resistant to powdery mildew (Brunner et al. 2012) is a good example of development answering a precise agronomic need. The new generation of genome editing technologies could empower local initiatives and responsive creation of varieties that may result in a more pragmatic way of using genetic technologies. As suggested recently and maybe counterintuitively (SCNAT 2013; Kahane et al. 2013; Jacobsen et al. 2013; Andersen et al. 2015; Palmgren et al. 2015; Jacobsen et al. 2015), the potential of modern plant breeding might be best exploited if associated with low-input systems such as organic or agro-ecological farming.

Acknowledgements The authors would like to thank the numerous experts and stakeholders involved: Swiss Farmer Union, Research Institute for Organic Agriculture (FiBL), Swiss Academies of Arts and Sciences (SCNAT), Foundation for Consumer Protection (SKS), Romand Consumer Federation (FRC), StopOGM, Gentechfree Swiss Alliance (SAG), sugar factories from Aarberg and Frauenfeld, Swiss Sugar Beet Centre, Swiss Agromarketing, Swisspatat, Swiss Birdlife, Fruit-Union Suisse. In particular, we would like to thank the Institute for Sustainability Science Agroscope for their support.

Open Access This article is distributed under the terms of the Creative Commons Attribution 4.0 International License (http:// creativecommons.org/licenses/by/4.0/), which permits unrestricted use, distribution, and reproduction in any medium, provided you give appropriate credit to the original author(s) and the source, provide a link to the Creative Commons license, and indicate if changes were made.

\section{References}

Abbas HK, Zablotowicz RM, Weaver MA et al (2013) Implications of Bt traits on mycotoxin contamination in maize: overview and recent experimental results in southern United States. In: Journal of Agricultural and Food Chemistry, pp 11759-11770. doi:10.1021/ jf400754g

Abrol DP (2012) Genetically modified plants and bees. In: Pollination Biology. Springer Netherlands, Dordrecht, pp 669-707. doi:10. 1007/978-94-007-1942-2

Aerni P, Scholderer J, Ermen D (2011) How would Swiss consumers decide if they had freedom of choice? Evidence from a field study with organic, conventional and GM corn bread. Food Policy 36: 830-838. doi:10.1016/j.foodpol.2011.08.002

Albisser Vögeli G, Burose F, Wolf D, Lips M (2011) Wirtschaflichkeit gentechnisch-veränderter Ackerkulturen in der Schweiz.

Andersen MM, Landes X, Xiang W et al (2015) Feasibility of new breeding techniques for organic farming. Trends Plant Sci 20:426-34. doi: 10.1016/j.tplants.2015.04.011

Babendreier D, Rostas M, Hofte MCJ et al (2003) Effects of mass releases of Trichogramma brassicae on predatory insects in maize. Entomol Exp Appl 108:115-124. doi:10.1046/j.15707458.2003.00075.x

Bartsch D, Schmidt M (1997) Influence of sugar beet breeding on populations of Beta vulgaris ssp. maritima in Italy. J Veg Sci 8:81-84. doi: $10.2307 / 3237245$

Baur P, Nitsch H (2013) Umwelt- und Tierschutz in der Landwirtschaft: Ein Vergleich der Schweiz mit ausgewählten europäischen Länderne unter besonderer Berücksichtigung des Vollzugs. FOAG Study. Agrofutura AG, Frick

Benbrook CM (2012) Impacts of genetically engineered crops on pesticide use in the U.S. - the first sixteen years. Environ Sci Eur 24:24. doi:10.1186/2190-4715-24-24

Bernard MB, Horne PA, Hoffmann AA (2004) Developing an ecotoxicological testing standard for predatory mites in Australia: acute and sublethal effects of fungicides on Euseius victoriensis and Galendromus occidentalis (Acarina: Phytoseiidae). J Econ Entomol 97:891-899. doi:10.1093/jee/97.3.891

Bigler F, Albajes R (2011) Indirect effects of genetically modified herbicide tolerant crops on biodiversity and ecosystem services: the biological control example. J für Verbraucherschutz und Leb 6:79-84. doi:10.1007/s00003-011-0688-1

Bock A, Lheureux K, Libeau-Dulos M, et al (2002) Scenario for coexistence of gemetically modified, conventional and organic crops in European agriculture. IPTS/DG JRC Technical Report. European Commission (EUR 20394 EN) Commissioned by the DirectorateGeneral for Agriculture

Bohanec M, Messéan A, Scatasta S et al (2008) A qualitative multiattribute model for economic and ecological assessment of genetically modified crops. Ecol Modell 215:247-261. doi:10.1016/j. ecolmodel.2008.02.016

Bohanec M, Žnidaršič M, Rajkovič V et al (2013) DEX methodology: three decades of qualitative multi-attribute modeling. Informatica $37: 49-54$

Bonfadelli H, Dahinden D, Leonarz M (2007) Mass media and public perceptions of red and green biotechnology: a case study from Switzerland. In: Brossard D (ed) The Media, the Public and Agricultural Biotechnology, CAB Intern., pp 97125

Brookes G, Barfoot P (2013) Key environmental impacts of global genetically modified (GM) crop use 1996-2011. GM Crops Food 4: 109-19. doi:10.4161/gmcr.24459

Brunner S, Stirnweis D, Diaz Quijano C et al (2012) Transgenic Pm3 multilines of wheat show increased powdery mildew resistance in 
the field. Plant Biotechnol J 10:398-409. doi:10.1111/j.1467-7652. 2011.00670.x

Bünemann EK, Schwenke GD, Van Zwieten L (2006) Impact of agricultural inputs on soil organisms - a review. Aust J Soil Res 44:379. doi:10.1071/SR05125

Catarino R, Ceddia G, Areal FJ, Park J (2015) The impact of secondary pests on Bacillus thuringiensis (Bt) crops. Plant Biotechnol J 13: 601-12. doi:10.1111/pbi.12363

Demont M, Devos Y (2008) Regulating coexistence of GM and non-GM crops without jeopardizing economic incentives. Trends Biotechnol 26:353-358. doi:10.1016/j.tibtech.2008.03.006

Devos Y, Demont M, Dillen K et al (2009) Coexistence of genetically modified (GM) and non-GM crops in the European Union. A review. Agron Sustain Dev 29:11-30. doi:10.1051/ agro:2008051

Devos Y, Dillen K, Demont M (2014) How can flexibility be integrated into coexistence regulations? A review. J Sci Food Agric 94:381387. doi:10.1002/jsfa. 6358

Edgerton MD, Fridgen J, Anderson JR et al (2012) Transgenic insect resistance traits increase corn yield and yield stability. Nat Biotechnol 30:493-496. doi:10.1038/nbt.2259

Fahrentrapp J, Broggini GAL, Kellerhals M et al (2013) A candidate gene for fire blight resistance in Malus $\times$ robusta 5 is coding for a CCNBS-LRR. Tree Genet Genomes 9:237-251. doi:10.1007/s11295012-0550-3

FAO (2015) Food and Agriculture Organization of the United Nations. http://www.fao.org

FOA (2014) Federal Office for Agriculture., Annual report, http://www. agrarbericht.ch

FOA (2015) Opinion polls. Accessed from http://www.agrarbericht.ch

Fernandez-Cornejo J, Wechsler S, Livingston M, Mitchell L (2014) Genetically engineerred crops in the United States

Gassmann AJ, Petzold-Maxwell JL, Keweshan RS, Dunbar MW (2011) Field-evolved resistance to Bt maize by Western corn rootworm. PLoS One. doi:10.1371/journal.pone.0022629

Geiger F, Bengtsson J, Berendse F et al (2010) Persistent negative effects of pesticides on biodiversity and biological control potential on European farmland. Basic Appl Ecol 11:97-105. doi:10.1016/j. baae.2009.12.001

Gene Technology Act. 914.91. http://www.admin.ch/opc/en/classifiedcompilation/19996136/index.html

Gomez-Barbero M, Berbel J, Rodriguez-Cerezo E (2008) Adoption and performance of the first GM crop introduced in EU agriclture. EUR 22778 EN. European Commission, Joint Research Centre

Granado J, Thürig B, Kieffer E et al (2008) Culturable fungi of stored "Golden Delicious" apple fruits: a one-season comparison study of organic and integrated production systems in Switzerland. Microb Ecol 56:720-732. doi:10.1007/s00248-008-9391-x

Green JM (2014) Current state of herbicides in herbicide-resistant crops. Pest Manag Sci 70:1351-1357

Gusberti M, Maurhofer Bringolf M, Klemm U, et al (2015) Fire blight: the fight goes on. Int. J. Environ. Res. Public Health 12(9):1142211447. doi:10.3390/ijerph120911422

Haughton AJ, Champion GT, Hawes C et al (2003) Invertebrate responses to the management of genetically modified herbicidetolerant and conventional spring crops. II. Within-field epigeal and aerial arthropods. Philos Trans R Soc B Biol Sci 358:1863-1877. doi:10.1098/rstb.2003.1408

Heinemann JA, Massaro M, Coray DS et al (2014) Sustainability and innovation in staple crop production in the US Midwest. Int J Agric Sustain 12:71-88. doi:10.1080/14735903.2013.806408

Hertfordshire University of (2015) Pesticide properties database. http:// sitem.herts.ac.uk/aeru/ppdb/en/

Hilbeck A, Binimelis R, Defarge N et al (2015) No scientific consensus on GMO safety. Environ Sci Eur 27:4. doi:10.1186/s12302-0140034-1
Hilbeck A, Meier M, Römbke J et al (2011) Environmental risk assessment of genetically modified plants - concepts and controversies. Environ Sci Eur 23:13. doi:10.1186/2190-4715-23-13

Hutchison WD, Burkness EC, Mitchell PD, et al (2010) Areawide suppression of European corn borer with Bt maize reaps savings to nonBt maize growers. Science (80-) 330:222-225. doi: 10.1126/ science.1190242

Hütter E, Bigler F, Fried P (2000) Transgene schädllingsresistente Pflanzen in der Schweiz? AGRARForschung 7:148-153

Icoz I, Stotzky G (2008) Fate and effects of insect-resistant Bt crops in soil ecosystems. Soil Biol Biochem 40:559-586. doi:10.1016/j. soilbio.2007.11.002

Jacobsen S-E, Sørensen M, Pedersen SM, Weiner J (2015) Using our agrobiodiversity: plant-based solutions to feed the world. Agron Sustain Dev. doi:10.1007/s13593-015-0325-y

Jacobsen S-E, Sørensen M, Pedersen SM, Weiner J (2013) Feeding the world: genetically modified crops versus agricultural biodiversity. Agron Sustain Dev 33:651-662. doi:10.1007/s13593-013-0138-9

Jin L, Zhang H, Lu Y et al (2015) Large-scale test of the natural refuge strategy for delaying insect resistance to transgenic Bt crops. Nat Biotechnol 33:169-74. doi:10.1038/nbt.3100

Jo K-R, Kim C-J, Kim S-J et al (2014) Development of late blight resistant potatoes by cisgene stacking. BMC Biotechnol 14:50. doi:10. 1186/1472-6750-14-50

Jorge MF-C, Caswell (2006) The first decade of genetically engineered crops in the United States.

Kahane R, Hodgkin T, Jaenicke H et al (2013) Agrobiodiversity for food security, health and income. Agron Sustain Dev 33:671-693. doi:10. 1007/s13593-013-0147-8

Klümper W, Qaim M (2014) A meta-analysis of the impacts of genetically modified crops. PLoS One 9, e111629. doi:10.1371/journal. pone.0111629

Kohler R (2005) Kosten der Koexistenz lanwitschaftlicher Anbausysteme mit oder ohne Gentechnil - eine Literaturanalyse.

Krato C, Hartung K, Petersen J (2012) Response of imidazolinonetolerant and -susceptible volunteer oilseed rape (Brassica napus L.) to ALS inhibitors and alternative herbicides. Pest Manag Sci 68: 1385-1392. doi:10.1002/ps.3317

Krens FA, Schaart JG, van der Burgh AM et al (2015) Cisgenic apple trees; development, characterization, and performance. Front Plant Sci. doi:10.3389/fpls.2015.00286

Lagnaoui A, Radcliffe EB (1998) Potato fungicides interfere with entomopathogenic fungi impacting population dynamics of green peach aphid. Am J Potato Res 75:19-25. doi:10.1007/BF02883513

Lang A, Vojtech E (2006) The effects of pollen consumption of transgenic Bt maize on the common swallowtail, Papilio machaon L. (Lepidoptera, Papilionidae). Basic Appl Ecol 7:296-306. doi:10. 1016/j.baae.2005.10.003

Li D-X, Tian J, Shen Z-R (2006) Effects of pesticides on the functional response of predatory thrips, Scolothrips takahashii to Tetranychus viennensis. J Appl Entomol 130:314-322. doi:10.1111/j.1439-0418. 2006.01056.x

Lichtfouse E, Navarrete M, Debaeke P et al (2009) Agronomy for sustainable agriculture. A review. Agron Sustain Dev 29:1-6. doi:10. 1051/agro:2008054

Lu Y, Wu K, Jiang Y et al (2012) Widespread adoption of Bt cotton and insecticide decrease promotes biocontrol services. Nature 487:362 365. doi:10.1038/nature11153

Meissle M, Romeis J, Bigler F (2011) Bt maize and integrated pest management — a European perspective. Pest Manag Sci 67:1049-1058

Melé E, Nadal A, Messeguer J et al (2015) Modeling gene flow distribution within conventional fields and development of a simplified sampling method to quantify adventitious GM contents in maize. Sci Rep 5:17106. doi:10.1038/srep17106 
Menrad K, Gabriel A, Gylling M (2009) Costs of co-existence and traceability systems in the food industry in Germany and Denmark. Paper prepared for presentation on GMCC 2009, Melbourne

Messean A, Angevin F, Gomez-Barbero M, et al (2006) New case studies on the coexistence og GM and non-GM crops in European agriculture. 1-112. EUR 22103 EN. European Commission Joint Research Centre

Mouron P, Heijne B, Naef A et al (2012) Sustainability assessment of crop protection systems: SustainOS methodology and its application for apple orchards. Agric Syst 113:1-15. doi:10.1016/j.agsy.2012.07.004

Nichterlein H, Matzk A, Kordas L et al (2013) Yield of glyphosateresistant sugar beets and efficiency of weed management systems with glyphosate and conventional herbicides under German and Polish crop production. Transgenic Res 22:725-736. doi:10.1007/ s11248-012-9678-z

Palmgren MG, Edenbrandt AK, Vedel SE et al (2015) Are we ready for back-to-nature crop breeding? Trends Plant Sci 20:155-64. doi:10. 1016/j.tplants.2014.11.003

Pelzer E, Fortino G, Bockstaller C et al (2012) Assessing innovative cropping systems with DEXiPM, a qualitative multi-criteria assessment tool derived from DEXi. Ecol Indic 18:171-182. doi:10.1016/ j.ecolind.2011.11.019

Price G, Falcl-Zepeda J, J F-C (2003) Size and distribution of market benefits from adopting biotech crops. USDA Report from the Economic Research Service. Number TN-1906

Raudonis L, Surviliene E, Valiuskaite A (2004) Toxicity of pesticides to predatory mites and insects in apple-tree site under field conditions. Environ Toxicol 19:291-295. doi:10.1002/tox.20036

Raymond Park J, McFarlane I, Hartley Phipps R, Ceddia G (2011) The role of transgenic crops in sustainable development. Plant Biotechnol J 9:2-21. doi:10.1111/j.1467-7652.2010.00565.x

Reim S, Flachowsky H, Michael M, Hanke MV (2006) Assessing gene flow in apple using a descendant of Malus sieversii var. sieversii $\mathrm{f}$. niedzwetzkyana as an identifier for pollen dispersal. Environ Biosafety Res 5:89-104. doi:10.1051/ebr:2006016

Romeis J, McLean MA, Shelton AM (2013) When bad science makes good headlines: Bt maize and regulatory bans. Nat Biotechnol 31: 386-387. doi:10.1038/nbt.2578

Rosi-Marshall EJ, Tank JL, Royer TV et al (2007) Toxins in transgenic crop byproducts may affect headwater stream ecosystems. Proc Natl Acad Sci U S A 104:16204-16208. doi:10.1073/pnas.0707177104

Russell AW (2008) GMOs and their contexts: a comparison of potential and actual performance of GM crops in a local agricultural setting. Geoforum 39:213-222. doi:10.1016/j.geoforum.2007.04.001

Sadok W, Angevin F, Bergez J-É et al (2009) Ex ante assessment of the sustainability of alternative cropping systems: implications for using multi-criteria decision-aid methods - a review. In: Sustainable Agriculture. Springer Netherlands, Dordrecht, pp 753-767

Sanchez-Bayo F, Hyne RV (2011) Comparison of environmental risks of pesticides between tropical and nontropical regions. Integr Environ Assess Manag 7:577-586. doi:10.1002/ieam.189

SCNAT (2013) Genetically modified cultivated plants and their impact on a sustainable agriculture in Switzerland. Report of the Swiss Academies of Arts and Sciences

Soane BD, Ball BC, Arvidsson J et al (2012) No-till in northern, western and south-western Europe: a review of problems and opportunities for crop production and the environment. Soil Tillage Res 118:6687. doi:10.1016/j.still.2011.10.015
Speiser B, Stolze M, Oehen B et al (2013) Sustainability assessment of GM crops in a Swiss agricultural context. Agron Sustain Dev 33: 21-61. doi:10.1007/s13593-012-0088-7

Steinbach HS, Alvarez R (2006) Changes in soil organic carbon contents and nitrous oxide emissions after introduction of no-till in Pampean agroecosystems. J Environ Qual 35:3-13. doi: 10.2134/ jeq2005.0050

Strandberg B, Pedersen M (2002) Biodiversity in glyphosate tolerant fodder beet fields. National Environmental Research Institute (NERI) Report $N^{\circ} 410$. Denmark

Sweet J, Bartsch D (2012) Synthesis and overview studies to evaluate existing research and knowledge on biological issues on GM plants of relevance to Swiss environments. vdf Zurich

Swiss Federal Council. (2016). Agenda 2030 for a Sustainable Development. http://www.are.admin.ch/themen/nachhaltig/00262/ 00528/index.html?lang=fr

Tabashnik BE, Finson N, Groeters FR et al (1994) Reversal of resistance to Bacillus thuringiensis in Plutella xylostella. Proc Natl Acad Sci U S A 91:4120-4124

Tabashnik BE, Unnithan GC, Masson L et al (2009) Asymmetrical crossresistance between Bacillus thuringiensis toxins Cry1 Ac and Cry2Ab in pink bollworm. Proc Natl Acad Sci U S A 106:11889 11894. doi:10.1073/pnas.0901351106

Turrini A, Sbrana C, Nuti MP et al (2005) Development of a model system to assess the impact of genetically modified corn and aubergine plants on arbuscular mycorrhizal fungi. Plant Soil 266:69-75. doi:10.1007/s11104-005-4892-6

Van Frankenhuyzen K (2013) Cross-order and cross-phylum activity of Bacillus thuringiensis pesticidal proteins. J Invertebr Pathol 114:76-85. doi:10.1016/j.jip.2013.05.010

Vanblaere T, Szankowski I, Schaart J et al (2011) The development of a cisgenic apple plant. J Biotechnol 154:304-311. doi:10.1016/j. jbiotec.2011.05.013

Vogler U, Rott AS, Gessler C, Dorn S (2010) How transgenic and classically bred apple genotypes affect non-target organisms on higher trophic levels. Entomol Exp Appl 134:114-121. doi:10.1111/j. 1570-7458.2009.00942.x

Vogt I, Wöhner T, Richter K et al (2013) Gene-for-gene relationship in the host-pathogen system Malus $\times$ robusta 5-Erwinia amylovora. New Phytol 197:1262-1275. doi:10.1111/nph.12094

Walsh F, Smith DP, Owens SM et al (2013) Restricted streptomycin use in apple orchards did not adversely alter the soil bacteria communities. Front Microbiol. doi:10.3389/fmicb.2013.00383

Wertz S, Degrange V, Prosser JI et al (2007) Decline of soil microbial diversity does not influence the resistance and resilience of key soil microbial functional groups following a model disturbance. Environ Microbiol 9:2211-2219. doi:10.1111/j.1462-2920. 2007.01335.x

Wolf D, Albisser Vögeli G (2009) ökonomischer Nutzen von Maïs Bt ist relativ. AGRARForschung 16:4-9

Wolt JD, Peterson RKD (2010) Prospective formulation of environmental risk assessments: probabilistic screening for Cry1A(b) maize risk to aquatic insects. Ecotoxicol Environ Saf 73:1182-1188. doi:10.1016/ j.ecoenv.2010.06.001

Zhao JH, Ho P, Azadi H (2011) Benefits of Bt cotton counterbalanced by secondary pests? Perceptions of ecological change in China. Environ Monit Assess 173:985-994. doi:10.1007/s10661-0101439-y 